\title{
Neutrophil Extracellular Traps Induced in Rheumatoid Arthritis Conditioned Animals are Inhibited Through Selenium Nanoparticles Supplementation
}

\section{Bo Zhang}

Beijing Chaoyang Hospital

\section{Xiao-Xiong Zhao}

Beijing University of Chinese Medicine

Yuan Lin

Beijing University of Technology Faculty of Information

Tong Chen

Beijing University of Technology Faculty of Information

Ren Shi-Xiang ( $\square$ rosonifzctxvs@gmail.com )

Beijing University of Technology Faculty of Information https://orcid.org/0000-0001-6816-1810

\section{Original article}

Keywords: NETs, Selenium nanoparticles, Rheumatoid arthritis

Posted Date: July 23rd, 2020

DOI: https://doi.org/10.21203/rs.3.rs-41615/v2

License: (c) (1) This work is licensed under a Creative Commons Attribution 4.0 International License.

Read Full License 
The authors have withdrawn this preprint from Research Square 